\title{
Pengembangan Kualitas Kepribadian Guru
}

\author{
Ahwy Oktradiksa \\ Universitas Islam Negeri Sunan Kalijaga Yogyakarta
}

\begin{abstract}
Teachers play a role in improving the quality of education. As individuals, the teacher is the embodiment of all the unique characteristics according to its position as the teaching profession stakeholders. Personality is the primary foundation for self-realization as an effective teacher in carrying out their professional duties. This requires a teacher to be able to realize effective personal to carry out the functions and responsibilities. Teachers must know himself and is able to develop in the direction of the realization of a healthy personal and plenary. Teacher's personality is an important factor for the success of ter-learning students. Personality of the teacher becomes an example for their students. Teacher's personality into the factors that determine good or bad personality of the child. Good personality became a teacher requirements.
\end{abstract}

Keywords: teachers, quality, personality.

\begin{abstract}
Abstrak
Guru memegang peran dalam peningkatan mutu pendidikan. Sebagai pribadi, guru merupakan perwujudan dari seluruh keunikan karakteristik yang sesuai dengan posisinya sebagai pemangku profesi keguruan. Kepribadian merupakan landasan utama bagi perwujudan diri sebagai guru yang efektif dalam melaksanakan tugas profesionalnya. Hal ini menuntut seorang guru harus mampu mewujudkan pribadi yang efektif untuk dapat melaksanakan fungsi dan tanggung jawabnya. Guru harus mengenal dirinya sendiri dan mampu mengembangkannya ke arah terwujudnya pribadi yang sehat dan paripurna. Kepribadian guru merupakan faktor terpenting bagi keberhasilan belajar anak didik. Kepribadian guru menjadi contoh bagi peserta didiknya. Kepribadian guru menjadi faktor yang menentukan baik atau buruknya kepribadian anak. Kepribadian yang baik menjadi persyaratan sorang guru.
\end{abstract}

Kunci kunci: guru, kualitas, kepribadian. 


\section{A. Pendahuluan}

Manusia pada dasarnya membutuhkan pendidikan, karena sudah menjadi kodratnya bahwa manusia harus di didik atau terdidik. Tanpa pendidikan manusia tidak akan berkembang. Dalam menciptakan manusia yang berpendidikan atau terdidik salah satu faktor pendukung utamanya adalah peranan seorang guru. Guru adalah orang yang berwenang dan bertanggung jawab untuk membimbing dan membina anak didik, baik secara individual, maupun klasik di sekolah maupun di luar sekolah. ${ }^{1}$ Sahabuddin mengemukakan bahwa pendidikan senantiasa merupakan faktor yang menentukan baik dalam arti dan peranan, maupun dalam kegunaannya, di mana pendidikan merupakan penentu hasil perpaduan antara peradaban dan kehancuran karena pendidikan juga tidak diperkuat, kehancuranlah yang akan memperoleh kesempatan karena pendidikan bertujuan agar manusia memiliki kelengkapan, baik fisik, emosional, maupun intelektual yang diperlukan agar dalam proses hidupannya selalu mampu menghadapi segala macam tantangan hidup. ${ }^{2}$

Pekerjaan sebagai guru adalah pekerjaan yang luhur dan mulia, baik ditinjau dari sudut masyarakat dan negara maupun ditinjau dari sudut keagamaan. Guru sebagai pendidik adalah seorang yang berjasa besar terhadap masyarakat dan negara. Tinggi atau rendahnya kebudayaan suatu masyarakat, maju atau mundurnya tingkat kebudayaan suatu masyarakat dan negara, sebagian besarnya tergantung kepada pendidikan dan pengajaran yang diberikan oleh guru-guru. Makin tinggi pendidikan guru, makin baik pula mutu pendidikan dan pengajaran yang diterima oleh anak-anak, dan makin tinggi pula derajat masyarakat. ${ }^{3}$ Oleh sebab itu, guru harus berkeyakinan dan bangga bahwa ia dapat menjalankan tugas itu. Guru hendaklah berusaha menjalankan tugas kewajiban sebaik-baiknya sehingga dengan demikian masyarakat menginsafi sungguh-sungguh betapa berat dan mulianya pekerjaan guru.

${ }^{1}$ Syaiful Djamarah, Guru dan Anak Didik dalam Interaksi Edukatif, (Banjarmasin: Rineka Cipta, 1977), hlm. 31.

2 Sahabuddin, Mengajar dan Belajar. (Makassar: State University of Makassar Press, 1999), hlm. 71.

3 Ngalim Purwanto, Ilmu Pendidikan Teoritis dan Praktis. (Jakarta: Remaja Rosdakarya, 1985), hlm. 32. 
Dengan kepercayaan yang diberikan masyarakat, maka di pundak guru diberikan tugas dan tanggung jawab yang berat. Mengemban tugas memang berat. Tapi lebih berat lagi mengemban tanggung jawab. Sebab tanggung jawab guru tidak hanya di sekolah, tetapi juga di luar sekolah. Di samping guru berperan sebagai pendidik atau pengajar yang merupakan faktor penentu kesuksesan setiap usaha pendidikan, faktor kepribadian seorang guru juga sangat berpengaruh terhadap keberhasilan seorang guru sebagai pengembang sumberdaya manusia, karena guru juga berperan sebagai "anutan". Kepribadian itulah yang akan menentukan apakah ia menjadi pendidik atau pembina yang baik bagi anak didiknya, atau malah jadi perusak bagi anak didiknya atau penghancur bagi masa depan anak didik terutama bagi anak didik yang masih kecil dan mereka mengelami keguncangan jiwa.

\section{B. Pembahasan}

1. Tanggung Jawab Guru

Tugas guru sebagai suatu profesi menuntut kepada guru untuk mengembangkan profesionalitas diri sesuai perkembangan ilmu pengetahuan dan teknologi. Mendidik, mengajar dan melatih anak didik adalah tugas guru sebagai suatu profesi. Tugas guru sebagai pendidik berarti meneruskan dan mengembangkan nilai-nilai hidup kepada anak didik, sedangkan tugas guru sebagai pengajar berarti meneruskan dan mengembangkan ilmu pengetahuan dan teknologi kepada anak didik. ${ }^{4}$ Maka tugas profesional dari seorang guru yaitu meneruskan atau transmisi ilmu pengetahuan, keterampilan dan nilai-nilai lain yang sejenis yang belum diketahui anak dan seharusnya diketahui oleh anak.

Adapun tugas atau peran guru yang dijelaskan oleh WF Connell (1972) sebagai pendidik, pertama, Peran guru sebagai pendidik (nurturer) merupakan peran-peran yang berkaitan dengan tugas-tugas memberi bantuan dan dorongan (supporter), tugas-tugas pengawasan dan pembinaan (supervisor) serta tugas-tugas yang berkaitan dengan mendisiplinkan anak agar anak itu menjadi patuh terhadap

\footnotetext{
${ }^{4}$ Rafli Kosasi, Profesi Keguruan, (Jakarta: Rineka Cipta, 1994), hlm.
} 74. 
aturan-aturan sekolah dan norma hidup dalam keluarga dan masyarakat. ${ }^{5}$ Tugas-tugas ini berkaitan dengan meningkatkan pertumbuhan dan perkembangan anak untuk memperoleh pengalaman-pengalaman lebih lanjut seperti penggunaan kesehatan jasmani, bebas dari orang tua, dan orang dewasa yang lain, moralitas tanggungjawab kemasyarakatan, pengetahuan dan keterampilan dasar, persiapan untuk perkawinan dan hidup berkeluarga, pemilihan jabatan, dan hal-hal yang bersifat personal dan spiritual. Oleh karena itu tugas guru dapat disebut pendidik dan pemeliharaan anak. Guru sebagai penanggung jawab pendisiplinan anak harus mengontrol setiap aktivitas anak-anak agar tingkat laku anak tidak menyimpang dengan norma-norma yang ada. Kedua, Peran guru sebagai pelajar (learner). Seorang guru dituntut untuk selalu menambah pengetahuan dan keterampilan agar supaya pengetahuan dan keterampilan yang dirnilikinya tidak ketinggalan jaman. Pengetahuan dan keterampilan yang dikuasai tidak hanya terbatas pada pengetahuan yang berkaitan dengan pengembangan tugas profesional, tetapi juga tugas kemasyarakatan maupun tugas kemanusiaan.

Dengan segala kekurangan yang ada, guru berusaha membimbing dan membina anak didik agar menjadi manusia yang berguna bagi nusa dan bangsa di kemudian hari. Gaji yang kecil jauh dari memadai, tidak membuat guru kecil-hati dengan sikap frustrasi meninggalkan tugas dan tanggung jawab sebagai guru. Karenanya sangat wajar di pundak guru diberikan atribut sebagai "Pahlawan tanpa tanda jasa". Menjadi guru berdasarkan tuntutan hati nurani tidaklah semua orang dapat melakukannya, untuk menjadi guru yang baik, tidak semua orang dapat menjalankannya. Selain untuk meyakinkan bahwa peran dan tantangan menjadi guru sangatlah besar, maka sebagai guru yang baik harus memenuhi syarat-syarat yang di dalam Undang-undang No. 12/1954 tentang Dasar-dasar Pendidikan dan Pengajaran di sekolah untuk seluruh Indonesia, pada pasal 15 sebagai berikut:

5 www.pakguruonline.com, Peran Guru dalam Pendidikan dan Masyarakat, diakses tanggal 20 Januari 2011. 
a. Berijazah, yakni dengan ijazah dapat memberi wewenang untuk menjalankan tugas sebagai guru di suatu sekolah. Ijazah adalah surat bukti yang menunjukkan bahwa seseorang telah mempunyai ilmu pengetahuan dan kesanggupan-kesanggupan tertentu yang diperlukannya untuk suatu jabatan atau pekerjaan. ${ }^{6}$

b. Sehat jasmani dan rohani, artinya kesehatan jasmani dan rohani adalah salah satu syarat yang penting bagi tiap-tiap pekerjaan. Orang tidak dapat melakukan tugasnya dengan baik jika badannya selalu diserang oleh suatu penyakit.

c. Takwa kepada Tuhan Yang Maha Esa dan berkelakuan baik, artinya pembentukan manusia susila yang takwa kepada Tuhan Yang Maha Esa hanya mungkin diberikan oleh orang-orang yang memiliki dan hidup sesuai dengan norma-norma agama dan masyarakat serta peraturan yang berlaku.

d. Bertanggung jawab, artinya dalam pembentukan warga negara yang demokratis dan bertanggung jawab itu sungguh suatu tugas tidak mudah, dan yang hanya dapat dilakukan oleh orang yang berjiwa demokratis dan yang mempunyai tanggungjawab pula. Tanlain dkk dalam Djamarah mengemukakan bahwa sesungguhnya guru yang bertanggung jawab memiliki beberapa sifat yaitu : menerima dan mematuhi norma, nilai-nilai kemanusiaan, memikul tugas mendidik dengan bebas, berani, gembira (tugas bukan menjadi beban baginya), sadar akan nilainilai yang berkaitan dengan perbuatannya serta akibatakibat yang timbul (kata hati), menghargai orang lain, termasuk anak didik, bijaksana dan hati-hati (tidak nekat, tidak sembrono, tidak singkat akal), takwa terhadap Tuhan Yang Maha Esa. ${ }^{7}$

e. Berjiwa nasional, artinya guru harus berjiwa nasional untuk mendidik anak-anak, sesuai dengan tujuan pendidikan dan pengajaran.

${ }^{6}$ Jamal Ma'ruf Asmani, 7 Kompetensi guru menyenagkan dan professional, (Yogyakarta: Power Books, 2009), hlm. 118-123.

${ }^{7}$ Syaiful Djamarah, Guru dan Anak Didik dalam ..., hlm. 36. 
Di samping syarat-syarat tersebut di atas masih banyak lagi syarat lain yang harus dimiliki oleh guru jika menghendaki agar tugas atau pekerjaannya sebagai guru mendatangkan hasil yang lebih baik. Ada beberapa syarat guru di sekolah adalah adil, percaya dan jika kepada muridmuridnya, sabar dan rela berkorban, memiliki wibawa terhadap anak-anak, penggembira, bersikap baik terhadap guru-guru lainnya, bersikap baik terhadap masyarakat, benarbenar menguasai mata pelajarannya, suka mata pelajaran yang diberikannya, berpengetahuan luas.

2. Kepribadian Guru

Kinerja peran guru dalam kaitan dengan mutu pendidikan harus dimulai dengan dirinya sendiri. Sebagai pribadi, guru merupakan perwujudan diri dengan seluruh keunikan karakteristik yang sesuai dengan posisinya sebagai pemangku profesi keguruan. Kepribadian merupakan landasan utama bagi perwujudan diri sebagai guru yang efektif baik dalam melaksanakan tugas profesionalnya di lingkungan pendidikan dan di lingkungan kehidupan lainnya. Hal ini mengandung makna bahwa seorang guru harus mampu mewujudkan pribadi yang efektif untuk dapat melaksanakan fungsi dan tanggung jawabnya sebagai guru. Untuk itu, ia harus mengenal dirinya sendiri dan mampu mengembangkannya ke arah terwujudnya pribadi yang sehat dan paripurna (fully functioning person).

Seorang guru dinilai tidak hanya dari aspek keilmuan saja, tapi juga dari aspek kepribadian yang ditampilkannya. Mampukah menarik anak didik dan memunculkan aura optimis dalam menghadapi berbagai tanggapan hidup, atau kepribadian yang acuh tak acuh, pesimis, dan tidak mampu memancarkan aura optimis, yang kesemuanya tercantum dalam konsep kepribadian. Menurut Theodore M. Newcomb diartikan sebagai organisasi sikap-sikap (predispositions) yang dimiliki oleh seseorang sebagai latar belakang terhadap perilaku. Yang mana organisasi tersebut yaitu bagaimana seseorang berbuat, mengetahui, berpikir, merasakan, dan menanggapi suatu keadaan. Kepribadian merupakan organisasi faktor-faktor biologis, psikologi, dan sosiologi yang mendasari perilaku individu. kepribadian mencangkup kebiasaan-kebiasaan, sikap, dan sifat lain yang khas dimiliki 
oleh seseorang yang berkembang apabila orang tadi berhubungan dengan orang lain. ${ }^{8}$

Seorang guru harus mempunyai kepribadian sehat yang akan mendorongnya mencapai puncak prestasi. Kepribadian yang sehat diartikan kepribadian yang secara fisik dan psikis terbebas dari penyakit tetapi bisa juga diartikan sebagai individu yang secara psikis selalu berusaha menjadi sehat. Adapun indikator yang terdapat pada kepribadian :

a. Bertanggung jawab. Tanggung jawab adalah perasaan kuat yang disertai kebulatan tekat untuk melaksanakan tugas dengan sebaik-baiknya. Tanggung jawab seorang guru adalah mengajar dan mendidik sekaligus. Ia harus disiplin, jujur, rajin beribadah, dan sungguh-sungguh memahamkan anak yang mana setiap saat mengembangkan diri agar anak didik tidak ketinggalan informasi dan pengetahuan.

b. Tidak emosional. Stabilitas emosi sangat penting bagi guru karena kondisi siswa yang berbeda, ada yang mudah di atur dan yang sulit, ada yang sengaja memancing emosi guru dan ada yang menggerutu dari belakang. Dari sini diperlukan stabilitas emosi, jangan sampai guru terpancing emosi yang nantinya bisa berakibat fatal kepada anak didik. Alangkah malunya kita melihat di televisi, berita seorang guru berurusan dengan polisi gara-gara memperlakukan anak didik dengan kekerasan.

c. Lemah lembut. Lemah lembut adalah cermin hati yang penyayang dan penuh penghormatan. Lemah lembut membuat murid segan, senang, dan hormat. Seorang guru yang berbicara sopan kepada muridnya akan dikenang murid dan membekas dalam hatinya. Guru yang suka menasehati, memperlakukan anak didik seperti anak sendiri, dan menolong kebutuhan muridnya akan dicintai.

d. Tegas tidak menakut-nakuti. Seorang guru harus tegas, adil dan tidak boleh membeda-bedakan. Jangan sampai menakut-nakuti dengan sesuatu yang tidak layak, misalnya di ancam dikeluarkan dari sekolah. Dipanggil orang tuannya, dan ancaman-ancaman kasar lainnya. Tegas dalam

\footnotetext{
${ }^{8}$ Moh. Roqib dan Nurfuadi, Kepribadian guru, upaya mengembangkan kepribadian guru yang sehat dimasa depan, (Yogyakarta: grafindolitera Media bekerjasama dengan STAIN Purwokerto, 2009), hlm. 15.
} 
pengertian konsisten menegakan aturan, dan berani bertanggung jawab terhadap perbuatan yang dilakukannya. Walaupun guru harus tegas, tapi cara yang dilakukan tetap tidak boleh kasar. Tegas bukan identik dengan kasar, tegas bisa dengan pendekatan yang humanis, persuasif, dan psikologis sehingga lebih bisa menyadarkan anak didik secara emosional.

b. Dekat dengan anak didik. Kedekatan membawa efek positif bagi pembelajaran. Kedekatan ini akan menciptakan hubungan batin dan keakraban dalam bergaul. Anak didik tidak takut bertanya dan berkonsultasi masalah yang dihadapi kepada gurunya. Lewat kedekatan inilah, murid akan tahu kebijakan guru, sikap perilaku guru, dan sepak terjang guru. Dan ini akan memunculkan inspirasi bagi peserta didik untuk meniru dan mengembangkan apa yang ada pada guru.

Setiap guru mempunyai pribadi masing-masing sesuai ciri-ciri pribadi yang mereka miliki. Ciri-ciri inilah yang membedakan seorang guru dari guru lainnya. Kepribadian merupakan suatu masalah yang abstrak, hanya dapat dilihat lewat penampilan, tindakan, ucapan, cara berpakaian, dan dalam menghadapi setiap persoalan. Kepribadian sesungguhnya adalah abstrak (ma'nawi), sukar dilihat atau diketahui secara nyata, yang dapat diketahui adalah penampilan atau bekasnya dalam segi dan aspek kehidupan. ${ }^{9}$ Oleh karena itu seluruh sikap dan perbuatan seseorang merupakan suatu gambaran dari kepribadian orang itu asal dilakukan secara sadar. kepribadian adalah suatu hal yang sangat menentukan tinggi rendahnya kewibawaan seorang guru dalam pandangan anak didik dan masyarakat. Kepribadian adalah faktor yang sangat berpengaruh terhadap keberhasilan seorang guru sebagai pengembang sumber daya manusia.

Karakteristik kepribadian yang berkaitan dengan keberhasilan guru dalam menggeluti profesinya adalah meliputi :

9 Syaiful Djamarah, 1977, Guru dan Anak Didik dalam Interaksi Edukatif, (Jakarta: Rineka Cipta), hlm. 36. 
a. Guru yang fleksibel pada umumnya ditandai dengan keterbukaan berpikir dan beradaptasi selain itu, guru juga memiliki resistensi (daya tahan) terhadap ketertutupan ranah cipta yang prematur (terlampau dini) dalam pengamatan dan pengenalan. Ketika mengamati dan mengenali suatu objek atau situasi tertentu. Seorang guru yang fleksibel selalu berpikir kritis. Berpikir kritis adalah berpikir dengan penuh pertimbangan akal sehat yang dipusatkan pada pengambilan keputusan untuk mempercayai atau melakukan atau menghindar sesuatu. Dalam proses belajar mengajar, fleksibilitas kognitif guru terdiri dari tiga dimensi yaitu: (1) dimensi karakteristik pribadi guru; (2) dimensi sikap kognitif guru terhadap siswa; (3) dimensi sikap kognitif guru terhadap mata pelajaran dan metode mengajar.

b. Guru yang terbuka secara psikologis biasanya ditandai dengan kesediaannya yang relatif tinggi untuk mengomunikasikan dirinya dengan faktor-faktor ekstern antara lain (1) siswa, (2) teman sejawat, dan (3) lingkungan pendidikan tempatnya bekerja. Ia mau menerima kritik dengan ikhlas. Di samping itu ia juga memiliki empati, yakni respons afektif terhadap pengalaman emosional dan perasaan tertentu orang lain. Ditinjau dari sudut fungsi dan signifikansi, keterbukaan psikologis merupakan karakteristik kepribadian yang penting bagi guru dalam hubungannya sebagai direktur belajar sebagai anutan siswa.

Banyak peranan yang diperlukan dari guru sebagai pendidik atau siapa saja yang telah menerjunkan diri menjadi guru. Dan oleh Djamarah mengemukakan beberapa peranan guru yaitu :(1) sebagai korektor (2) sebagai inspirator (3) sebagai informator (4) sebagai organisator (5) sebagai motivator (6) sebagai inisiator (7) sebagai fasilitator (8) sebagai pembimbing (9) sebagai pengelola kelas (10) sebagai mediator (11) sebagai demonstrator (12) sebagai supervisor (13) sebagai evaluator. Guru dan anak didik adalah Dwi Tunggal. ${ }^{10}$ Yang mana posisi guru dan anak boleh berbeda, tetapi keduanya tetap seiring dan setujuan, bukan seiring tapi tidak setujuan. Seiring dalam arti kesamaan langkah dalam

\footnotetext{
${ }^{10}$ Syaiful Djamarah, Guru dan Anak Didik ..., hlm. 43.
} 
mencapai tujuan bersama. Anak didik berusaha mencapai citacitanya dan guru dengan ikhlas mengantar dan membimbing anak didik ke pintu gerbang cita-citanya. Itulah sikap guru yang tepat sebagai sosok pribadi yang mulia. Pendek kata kewajiban guru adalah menciptakan manusia yang baik.

3. Kompetensi Kepribadian sebagai bentuk pengembangan kepribadian guru.

Sebagaimana di jelaskan dalam Peraturan Menteri Pendidikan Nasional RI No. 16 tahun 2007 tentang Standar Kualifikasi Akademik dan Kompetensi Guru. ${ }^{11}$ Hal ini mengisyaratkan bahwa perubahan dan pembaharuan sistem pendidikan sangat tergantung pada penguasaan kompetensi guru. Oleh karena itu harus ada upaya yang komprehensif guna meningkatkan kompetensi guru dalam hal ini dalam kompetensi kepribadian. Adapun kompetensi yang dikembangkan secara utuh dari kompetensi kepribadian di antaranya :

a. Bertindak sesuai dengan norma agama, hukum, sosial, dan kebudayaan nasional Indonesia.

b. Menampilkan diri sebagai pribadi yang jujur, berakhlak mulia, dan teladan bagi peserta didik dan masyarakat.

c. Menampilkan diri sebagai pribadi yang mantap, stabil, dewasa, arif, dan berwibawa.

d. Menunjukkan etos kerja, tanggung jawab yang tinggi, rasa bangga menjadi guru, dan rasa percaya diri.

b. Menjunjung tinggi kode etik guru. ${ }^{12}$

Guru sebagai tenaga pendidik yang tugas utamanya mengajar, memiliki karakteristik kepribadian yang sangat berpengaruh terhadap keberhasilan pengembangan sumber daya manusia. Kepribadian yang mantap dari sosok seorang guru akan memberikan teladan yang baik terhadap anak didik maupun masyarakatnya, sehingga guru akan tampil sebagai sosok yang patut "digugu" (ditaati nasehat/ucapan/ perintahnya) dan "ditiru" (di contoh sikap dan perilakunya).

11 Himpunan Undang-Undang Republik Indonesia, Guru dan Dosen, sistem Pendidikan Nasional, Standar Nasional Pendidikan, (Surabaya: Wacana Intelektual, 2009), hlm. 55.

${ }^{12}$ Himpunan Undang-Undang Republik Indonesia, Guru dan Dosen.., hlm. 71 . 
Kepribadian guru merupakan faktor terpenting bagi keberhasilan belajar anak didik. Dalam kaitan ini, Zakiah Darajat dalam Syah menegaskan bahwa kepribadian itulah yang akan menentukan apakah ia menjadi pendidik dan pembina yang baik bagi anak didiknya, ataukah akan menjadi perusak atau penghancur bagi masa depan anak didiknya terutama bagi anak didik yang masih kecil (tingkat dasar) dan mereka yang sedang mengalami keguncangan jiwa (tingkat menengah). ${ }^{13}$

Karakteristik kepribadian yang berkaitan dengan keberhasilan guru dalam menggeluti profesinya adalah meliputi fleksibilitas kognitif dan keterbukaan psikologis. Fleksibilitas kognitif atau keluwesan ranah cipta merupakan kemampuan berpikir yang diikuti dengan tindakan secara simultan dan memadai dalam situasi tertentu. Guru yang fleksibel pada umumnya ditandai dengan adanya keterbukaan berpikir dan beradaptasi. Selain itu, ia memiliki resistensi atau daya tahan terhadap ketertutupan ranah cipta yang prematur dalam pengamatan dan pengenalan. Dalam Undang-undang Guru dan Dosen dikemukakan kompetensi kepribadian adalah "kemampuan kepribadian yang mantap, berakhlak mulia, arif, dan berwibawa serta menjadi teladan peserta didik". Surya menyebut kompetensi kepribadian ini sebagai kompetensi personal, yaitu kemampuan pribadi seorang guru yang diperlukan agar dapat menjadi guru yang baik. ${ }^{14}$ Kompetensi personal ini mencakup kemampuan pribadi yang berkenaan dengan pemahaman diri, penerimaan diri, pengarahan diri, dan perwujudan diri.

4. Pendidikan Karakter dalam Pembentukan Kepribadian

Sebagai upaya untuk meningkatkan kesesuaian dan mutu pendidikan karakter, Kementrian Pendidikan Nasional mengembangkan grand design pendidikan karakter untuk setiap jalur, jenjang, dan jenis satuan pendidikan. Grand design menjadi rujukan konseptual dan operasional pengembangan, pelaksanaan, dan penilaian pada setiap jalur dan jenjang pendidikan. Konfigurasi karakter dalam konteks

13 Muhibbin Syah, Psikologi Pendidikan dengan Pendekatan Baru. (Bandung: Remaja Rosdakarya, 2000), Hal. 225-226.

${ }^{14}$ Muhammad Surya, Psikologi Pembelajaran dan Pengajaran. (Bandung: Yayasan Bhakti Winaya, 2003), hlm. 138. 
totalitas proses psikologis dan sosial-kultural tersebut dikelompokkan dalam: Olah Hati (Spiritual and emotional development), Olah Pikir (intellectual development), Olah Raga dan Kinestetik (Physical and kinestetic development), dan Olah Rasa dan Karsa (Affective and Creativity development). Pengembangan dan implementasi pendidikan karakter perlu dilakukan dengan mengacu pada grand design tersebut.

Keberhasilan pendidikan karakter dalam pembentukan kepribadian dapat diketahui melalui pencapaian indikator oleh peserta didik sebagaimana tercantum dalam Peraturan Menteri Pendidikan Nasional No 23 tahun 2006 Standar Kompetensi Lulusan Satuan Pendidikan, yang antara lain meliputi sebagai berikut: ${ }^{15}$

a. Mengamalkan ajaran agama yang dianut sesuai dengan tahap perkembangan remaja;

b. Memahami kekurangan dan kelebihan diri sendiri;

c. Menunjukkan sikap percaya diri;

d. Mematuhi aturan-aturan sosial yang berlaku dalam lingkungan yang lebih luas;

e. Menghargai keberagaman agama, budaya, suku, ras, dan golongan sosial ekonomi dalam lingkup nasional;

f. Mencari dan menerapkan informasi dari lingkungan sekitar dan sumber-sumber lain secara logis, kritis, dan kreatif;

g. Menunjukkan kemampuan berpikir logis, kritis, kreatif, dan inovatif;

h. Menunjukkan kemampuan belajar secara mandiri sesuai dengan potensi yang dimilikinya;

i. Menunjukkan kemampuan menganalisis dan memecahkan masalah dalam kehidupan sehari-hari;

j. Mendeskripsikan gejala alam dan sosial;

k. Memanfaatkan lingkungan secara bertanggung jawab;

1. Menerapkan nilai-nilai kebersamaan dalam kehidupan bermasyarakat, berbangsa, dan bernegara demi terwujudnya persatuan dalam negara kesatuan Republik Indonesia;

${ }^{15}$ Himpunan Undang-Undang Republik Indonesia, Guru dan Dosen..., hlm. 235 . 
m. Menghargai karya seni dan budaya nasional;

n. Menghargai tugas pekerjaan dan memiliki kemampuan untuk berkarya;

o. Menerapkan hidup bersih, sehat, bugar, aman, dan memanfaatkan waktu luang dengan baik;

p. Berkomunikasi dan berinteraksi secara efektif dan santun;

q. Memahami hak dan kewajiban diri dan orang lain dalam pergaulan di masyarakat; Menghargai adanya perbedaan pendapat;

r. Menunjukkan kegemaran membaca dan menulis naskah pendek sederhana;

s. Menunjukkan keterampilan menyimak, berbicara, membaca, dan menulis dalam bahasa Indonesia dan bahasa Inggris sederhana;

t. Menguasai pengetahuan yang diperlukan untuk mengikuti pendidikan menengah;

u. Memiliki jiwa kewirausahaan.

Guru adalah pelaku perubahan. Gagasan ini menjadikan guru harus peka dan tanggap terhadap berbagai perubahan, pembaharuan serta perkembangan ilmu pengetahuan dan teknologi sejalan dengan tuntutan masyarakat dan perkembangan zaman. Di sinilah tugas guru semestinya harus senantiasa mengembangkan wawasan ilmu pengetahuan, meningkatkan kualitas pendidikannya hingga apa yang diberikan kepada peserta didiknya tidak lagi terkesan ketinggalan zaman. Bahkan tidak sesederhana itu saja, ciri guru ideal di era globalisasi seperti saat ini perlu tampil sebagai pendidik, pengajar, pelatih, inovator dan dinamisator secara sekaligus dan integral dalam mencerdaskan anak didiknya. Salah satu indikator utama unggul tidaknya sebuah sekolah adalah ditentukan dari faktor mutu guru. Guru dituntut memiliki profesionalisme di bidangnya. Artinya guru tidak hanya harus memiliki pengetahuan yang luas tentang bidang yang ajarnya, namun seluruh komponen yang berkaitan dengan pendidikan harus ada pada diri para guru itu sendiri. Hal itu pula didasarkan atas asumsi bahwa persoalan peningkatan mutu pendidikan tentu bertolak pada karakter seorang pendidik. Oleh sebab itu, semakin banyak guru yang 
berkualitas di suatu sekolah, tentu akan semakin berkualitas pulalah sekolah tersebut. ${ }^{16}$

Sosok guru merupakan hal paling utama bagi keberhasilan suatu sistem pendidikan. Di tengah kemajuan zaman dan tantangan yang semakin pesat, idealnya guru harus terus belajar, kreatif mengembangkan diri dan terus menyesuaikan pengetahuan dan cara mengajarnya dengan penemuan-penemuan kontemporer. Namun, realitas yang ada pada umumnya guru sulit untuk selalu semangat mengembangkan kepribadiannya. Bahkan sekedar untuk mengikuti berbagai macam kursus, seminar, pelatihan dan kegiatan semacamnya.

5. Kepribadian Guru Memunculkan Sosok Guru Ideal

Guru ideal adalah dambaan peserta didik. Guru ideal adalah sosok guru yang mampu untuk menjadi panutan dan selalu memberikan keteladanan. Ilmunya seperti mata air yang tak pernah habis. Semakin diambil semakin jernih airnya. Mengalir bening dan menghilangkan rasa dahaga bagi siapa saja yang meminumnya. Guru ideal adalah guru yang mengusai ilmunya dengan baik. Mampu menjelaskan dengan baik apa yang diajarkannya. Disukai oleh peserta didiknya karena cara mengajarnya yang enak didengar dan mudah dipahami. Ilmunya mengalir deras dan terus bersemi di hati para anak didiknya. Guru ideal yang diperlukan saat ini adalah:

a. Guru yang memahami benar akan profesinya. Profesi guru adalah profesi yang mulia. Dia adalah sosok yang selalu memberi dengan tulus dan tak mengharapkan imbalan apapun, kecuali rida dari Tuhan pemilik bumi. Falsafah hidupnya adalah tangan di atas lebih mulia daripada tangan di bawah. Hanya memberi tak harap kembali. Dia mendidik dengan hatinya. Kehadirannya dirindukan oleh peserta didiknya. Wajahnya selalu ceria, senang, dan selalu menerapkan 5S dalam kesehariannya (Salam, Sapa, Sopan, Senyum, dan Sabar).

${ }^{16}$ Doni Koesoema A, (Resume oleh : Ahmad Makki Hasan Mahasiswa Program Pascasarjana UIN Malang dan Guru SMA Negeri 1 Kota Malang), Mengembangkan Visi Guru sebagai Pelaku Perubahan dan Pendidik Karakter, (Jakarta: Grasindo 2009),hlm. 7. 
b. Guru yang ideal adalah guru yang rajin membaca dan menulis. Pengalaman mengatakan, siapa yang rajin membaca, maka ia akan kaya akan ilmu. Namun, bila kita malas membaca, maka kemiskinan ilmu akan terasa. Guru yang rajin membaca otaknya seperti komputer atau ibarat mesin pencari "Google" di internet. Bila ada peserta didiknya yang bertanya, memori otaknya langsung bekerja mencari dan menjawab pertanyaan para anak didiknya dengan cepat dan benar. Akan terlihat wawasan guru yang rajin membaca, dari cara bicara dan menyampaikan pengajarannya.

c. Guru yang ideal adalah guru yang juga rajin menulis. Bila guru malas membaca, maka sudah bisa dipastikan dia akan malas pula untuk menulis. Menulis dan membaca adalah kepingan mata uang logam yang tidak dapat dipisahkan. Guru yang terbiasa membaca, maka ia akan terbiasa menulis, karena dari membaca itulah guru mampu membuat kesimpulan dari apa yang dibacanya, kemudian kesimpulan itu ia tuliskan kembali dalam gaya bahasanya sendiri. Menulis itu ibarat pisau yang kalau tidak sering diasah, maka akan tumpul dan berkarat. Guru yang rajin menulis, akan mempunyai kekuatan tulisan yang sangat tajam, layaknya sebilah pisau. Tulisannya sangat menyentuh hati, dan bermakna. Runut serta mudah dicerna bagi siapa saja yang membacanya.

d. Guru yang ideal adalah guru yang sensitif terhadap waktu. Orang Barat mengatakan bahwa waktu adalah uang, time is money. Bagi guru waktu lebih dari uang dan bahkan bagaikan sebilah pedang tajam yang dapat membunuh siapa saja termasuk pemiliknya. Pedang yang tajam bisa berguna untuk membantu guru menghadapi hidup ini, namun bisa juga sebagai pembunuh dirinya sendiri. Bagi guru yang kurang memanfaatkan waktunya dengan baik, maka tidak akan banyak prestasi yang ia raih dalam hidupnya. Dia akan terbunuh oleh waktu yang ia sia-siakan. Karena itu guru harus sensitif terhadap waktu. Detik demi detik waktunya teratur dan terjaga dari sesuatu yang kurang baik serta sangat berharga. Saat kita menganggap waktu tidak berharga, maka waktu akan menjadikan kita manusia tidak berharga. Demikian pula saat kita 
memuliakan waktu, maka waktu akan menjadikan kita orang mulia. Karena itu, kualitas seseorang terlihat dari cara ia memperlakukan waktu dengan baik.

e. Guru yang ideal adalah guru yang kreatif dan inovatif. Merasa sudah berpengalaman membuat guru menjadi kurang kreatif. Guru malas mencoba sesuatu yang baru dalam pembelajarannya. Dia merasa sudah cukup. Tidak ada upaya untuk menciptakan sesuatu yang baru dari pembelajarannya. Dari tahun ke tahun gaya mengajarnya itu-itu saja. Rencana Pelaksanaan Pembelajaran (RPP) yang dibuat pun dari tahun ke tahun sama, hanya sekedar copy and paste tanggal dan tahun saja. RPP tinggal menyalin dari kurikulum yang dibuat oleh pemerintah atau menyontek dari guru lainnya. Guru menjadi tidak kreatif. Proses kreatif menjadi tidak jalan. Untuk melakukan suatu proses kreatif dibutuhkan kemauan untuk melakukan inovasi yang terus menerus, tiada henti. Guru yang kreatif adalah guru yang selalu bertanya pada dirinya sendiri. Apakah dia sudah menjadi guru yang baik? Apakah dia sudah mendidik dengan benar? Apakah anak didiknya mengerti tentang apa yang dia sampaikan? Dia selalu memperbaiki diri. Dia selalu merasa kurang dalam proses pembelajarannya. Dia tidak pernah puas dengan apa yang dia lakukan. Selalu ada inovasi baru yang dia ciptakan dalam proses pembelajarannya. Dia selalu memperbaiki proses pembelajarannya melalui Penelitian Tindakan Kelas (PTK). Dia selalu belajar sesuatu yang baru, dan merasa tertarik untuk membenahi cara mengajarnya. Dia senantiasa belajar sepanjang hayat hidupnya.

f. Guru yang ideal adalah guru yang memiliki 5 kecerdasan. Kecerdasan yang dimiliki terpancar jelas dari karakter dan prilakunya sehari-hari. Baik ketika mengajar, ataupun dalam hidup di tengah-tengah masyarakat. Kelima kecerdasan itu adalah: kecerdasan intelektual, kecerdasan moral, kecerdasan sosial, kecerdasan emosional, kecerdasan motorik. Kecerdasan intelektual harus diimbangi dengan kecerdasan moral, Mengapa? Bila kecerdasan intelektual tidak diimbangi dengan kecerdasan moral akan menghasilkan peserta didik yang hanya mementingkan 
keberhasilan ketimbang proses, segala cara dianggap halal, yang penting target tercapai semaksimal mungkin.

Inilah yang terjadi pada masyarakat kita sehingga kasus korupsi merajalela di kalangan orang terdidik. Karena itu kecerdasan moral akan mengawal kecerdasan intelektual sehingga akan mampu berlaku jujur dalam situasi apapun. Jujur bukanlah kebijakan yang terbaik, tetapi jujur adalah satu-satunya kebijakan karena kejujuran adalah kunci keberhasilan dan kesuksesan. Selain itu kecerdasan sosial juga harus dimiliki oleh guru ideal agar tidak egois, dan tidak mempedulikan orang lain. Dia harus mampu bekerjasama dengan karakter orang lain yang berbeda. Kecerdasan emosional harus ditumbuhkan agar guru tidak gampang marah, tersinggung, dan mudah melecehkan orang lain. Sedangkan kecerdasan motorik diperlukan agar guru mampu melakukan mobilitas tinggi sehingga mampu bersaing dalam memperoleh hasil yang maksimal.

\section{Penutup}

Tidak semua orang bisa dan ingin menjadi guru yang berwibawa, dihormati, berwawasan luas dan berstatus tinggi di hadapan setiap orang karena orang yang ingin mengabdikan hidupnya dan mengemban tugas ini benar-benar harus mempunyai jiwa kepatriotan yang tugas, lugas dan bertanggung jawab atas masa depan setiap orang. Kepribadian yang baik sangat berpengaruh terhadap perkembangan jiwa seseorang begitu juga dengan guru yang mempunyai kepribadian akan menentukan sejauh mana ia akan membawa semua potensi yang ada pada siswa. Kemudian kepribadian itulah yang akan menentukan apakah ia menjadi pendidik dan pembina yang baik bagi anak didiknya, ataukah akan menjadi perusak atau penghancur bagi masa depan anak didiknya.

Guru ideal adalah sosok guru yang mampu untuk menjadi panutan dan selalu memberikan keteladanan. Ilmunya seperti mata air yang tak pernah habis. Semakin diambil semakin jernih airnya. Mengalir bening dan menghilangkan rasa dahaga bagi siapa saja yang meminumnya. Guru ideal adalah guru yang mengusai ilmunya dengan baik. Mampu menjelaskan dengan baik apa yang 
diajarkannya. Disukai oleh peserta didiknya karena cara mengajarnya yang enak didengar dan mudah dipahami.

\section{Kepustakaan}

Anwar, Moch. Idochi. 2004. Administrasi Pendidikan dan Manajemen Biaya Pendidikan. Bandung: Alfabeta.

Arikunto, Suharsimi. 1993. Manajemen Pengajaran Secara Manusia. Jakarta: Rineka Cipta.

Asmani, Jamal Ma'ruf. 2009. 7 Kompetensi Guru Menyenangkan dan Professional. Yogyakarta: Power Books.

Djamarah, Syaiful. 1977. Guru dan Anak Didik dalam Interaksi Edukatif. Banjarmasin: Rineka Cipta.

Himpunan Undang-Undang Republik Indonesia. 2009. Guru dan Dosen, Sistem Pendidikan Nasional, Standar Nasional Pendidikan. Surabaya : Wacana Intelektual.

Kosasi, Rafli. 1994. Profesi Keguruan. Jakarta: Rineka Cipta.

Koesoema, Doni. 2009. (Resume oleh: Ahmad Makki Hasan Mahasiswa Program Pascasarjana UIN Malang dan Guru SMA Negeri 1 Kota Malang), Mengembangkan Visi Guru sebagai Pelaku Perubahan dan Pendidik Karakter. Jakarta: Grasindo.

Mulyasa. 2006. Menjadi Guru Profesional. Bandung: Remaja Rosdakarya.

Roqib, Moh. dan Nurfuadi. 2009. Kepribadian Guru, Upaya Mengembangkan Kepribadian Guru yang Sehat Dimasa Depan.Yogyakarta: Grafindolitera Media bekerjasama dengan STAIN Purwokerto.

Purwanto, Ngalim. 1985. Ilmu Pendidikan Teoritis dan Praktis. Jakarta: Remaja Rosdakarya.

Sahabuddin. 1999. Mengajar dan Belajar. Makassar: State University of Makassar Press.

Syah, Muhibbin. 2000. Psikologi Pendidikan dengan Pendekatan Baru. Bandung: Remaja Rosdakarya.

Surya, Muhammad. 2003. Psikologi Pembelajaran dan Pengajaran. Bandung: Yayasan Bhakti Winaya. 
